\title{
A Single-Season Irrigated Rice Soil Presents Higher Iron Toxicity Risk in Tropical Savannah Valley Bottoms
}

\author{
Amadou Keita ${ }^{1 *}$, Hamma Yacouba ${ }^{1}$, Laszlo G. Hayde ${ }^{2}$, Bart Schultz $^{2}$ \\ ${ }^{1}$ Joint Research Centre for Water and Climate, International Institute for Water and Environmental Engineering (2iE), Ouagadougou, \\ Burkina Faso; ${ }^{2}$ Department of Water Science and Engineering, UNESCO-IHE-Institute for Water Education, Delft, The Netherlands. \\ Email:*amadou.keita@2ie-edu.org,ama_keita@yahoo.fr
}

Received October $11^{\text {th }}, 2013$; revised November $11^{\text {th }}, 2013$; accepted November $18^{\text {th }}, 2013$

Copyright (C) 2013 Amadou Keita et al. This is an open access article distributed under the Creative Commons Attribution License, which permits unrestricted use, distribution, and reproduction in any medium, provided the original work is properly cited.

\begin{abstract}
With the aim of finding the geochemical differences and helping to build alleviating strategies against iron toxicity, two hematite dominant valley bottoms irrigating rice soils were investigated in the Tropical Savannah region of Burkina Faso. The first site was Tiefora, a 15-ha modern double-season irrigated rice system and moderately affected by iron toxicity ( $10 \%$ of the area with a toxicity score of 4$)$. The second site was Moussodougou, a 35-ha traditional singleseason irrigated rice valley-bottom, with 50\% facing more severe iron toxicity (score 7). Nine soil extracts were taken from three depths-30, 50 and $100 \mathrm{~cm}$ - i.e. 27 at Tiefora and 27 at Moussodogou. Five techniques were used to measure the data: 1) the ferrous iron concentration was determined using a reflectometer, 2) a $\mathrm{pH}$-meter yielded the $\mathrm{pH}, 3$ ) clay-proportions were obtained by United States Department of Agriculture (USDA) grain size analysis and densitometry, 4) the organic matter was determined by oven drying $\left(900^{\circ} \mathrm{C}\right)$ and v) the dry bulk density was determined by using undisturbed soil samples. Statistical hypothesis testing of One-way ANOVA and Welch t-test was applied to the data to isolate the similarities and the differences between the two sites. A geochemical analysis followed to find the causes of these differences. The results showed that while oxidation of pyrite leads to a simultaneous increase in $\mathrm{Fe}^{2+}$ concentrations and acidity in the soils of coastal floodplains and mangroves, the oxidation of hematite in Tropical savannah valley bottoms decreases $\mathrm{Fe}^{2+}$ but also increases acidity during the dry season. As a consequence, it was found that the single-season irrigation scheme of Moussodougou is significantly (p-value $0.4 \%$ ) more acidic $(\mathrm{pH} 5.7)$ than the double-season system of Tiefora (6.4) with also 750 - $1800 \mathrm{mg} / \mathrm{l} \mathrm{higher} \mathrm{ferrous} \mathrm{Fe}^{2+}$. The ferrous iron reached $3000 \mathrm{mg} / \mathrm{l}$ in some layers in Moussodougou. This result is a justification to modernize a traditional single-season spate irrigation scheme into a double-season irrigated rice scheme.
\end{abstract}

Keywords: ANOVA; Burkina Faso; Hematite; Iron Toxicity; Rice; Soil Sampling; Tropical Savannah; Valley Bottoms; Welch T-Test

\section{Introduction}

Rice is a global cereal facing yield growth challenges in several regions. It is currently consumed by more than 3 billion people and is cultivated on more than 15.5 million ha [1]. Food security challenge is closely linked to rice production since this cereal is essentially self-consumed, being internationally marketed for only 7\% [2]. Nevertheless, rice yield is either stagnant or declining in several regions since 1990s [3]. In fact, if the current production trend had to continue, the cereal food availability estimated to $150 \mathrm{~kg} /$ person in 2005 will drop to 130 kg/person by 2035 [4].

${ }^{*}$ Corresponding author.
About $10 \%$ of the crop farming areas are found in valley bottoms in the Tropical Savannah of West Africa, where exploitation focuses on rice production but also faces a yield decline [5]. The West African rice production only covers $50 \%$ of the needs and thus most of the countries in the region are rice importers [6]. Nigeria, Senegal and Ivory Coast are among the biggest importers [2]. In Burkina Faso, the importation was estimated to more than 210,000 tons in 2010 [7,8]. Iron toxicity is one of the most important constraints to yield growth in Tropical Savannah valley bottoms, threatening up to $60 \%$ of the swampy area, with a yield reduction of $10 \%-100 \%$ [9]. In Burkina Faso, 300 ha ferrous iron intoxicated soils were abandoned in the Vallée du Kou in 1986, most of 
which remained uncultivated up to date [10].

Iron toxicity issue in West African Tropical Savannah is currently addressed by various fields of research. In agronomy, Africa Rice devotes an important effort in the development of ferrous iron resistant cultivars $[9,11]$. Microbiology strives to identify and quantify the bacterial activities involved in the redox processes, occurring in the rice irrigated valley bottoms, in order to propose chemical and/or biotechnological means of reclamation $[10,12]$. Still, one cannot find in the current research any study comparing a traditional single-season spate irrigated rice soil with a double-season modern irrigation system in terms of acidity and ferrous iron concentrations threats. Such a comparison can lead to a better understanding of the processes and to different alleviation strategies against iron toxicity. Our study was carried out taking this view point and the results are presented in this paper.

\section{Materials and Methods}

\subsection{Sites Location}

The two sites present remarkable similar but also contrasting features. For example, both are located in valley bottoms at the heart of the Tropical Savannah zone of Burkina Faso. The coordinates Tiefora are $10^{\circ} 37^{\prime} 33.56^{\prime \prime} \mathrm{N}$ and $4^{\circ} 33^{\prime} 13.19 " \mathrm{~W}$, while Moussodougou is situated at $10^{\circ} 52^{\prime} 18.32 " \mathrm{~N}$ and $4^{\circ} 55^{\prime} 16.19 " \mathrm{~W}$. These zones are Tropical Savannah [13], with $1200 \mathrm{~mm} / \mathrm{yr}$ rainfall, falling only within four to five months, from May to October. The soils in the environment are essentially made of hematite $\left(\mathrm{Fe}_{2} \mathrm{O}_{3}\right)$ [14]. Both sites are exploited by a farmer's organizations, though bigger in Moussodougou (35 ha) than in Tiefora (16 ha). The farm plot sizes range from 0.15 up to 0.50 ha per farmer in both sites. In fact, an important contrast is the number of rice growing seasons: Tiefora with its lined irrigation tertiary canals practices two rice growing seasons using gravity water from a $500,000 \mathrm{~m}^{3}$ reservoir, while Moussodougou is watered only during the rainy season from the spate of the river passing the middle of the quasi-symmetric valley bottom (Figure 1).

\subsection{Soil Sampling}

The procedure strove to avoid bias while collecting soil extracts from these colluvio-alluvial valley bottoms. Both valleys possess longitudinal and transversal slopes making possible the occurrence of different thicknesses of clay or concentration of ferrous iron for example. Therefore a randomized block sampling was used $[15,16]$. The valley was divided into three zones longitudinally and three zones transversally. The longitudinal axis was assumed to be the line of the main irrigation canal passing through the middle of the valley in Tiefora, while it coin- cides with the river bed in Moussodougou. Considering the symmetrical shape of this second valley, the soils extracted from the rightbank of the river are assumed to present similar properties than the corresponding investigated area on the leftbank (Figure 1). In Tiefora, the soil extracts where taken from both sides of the asymmetric valley [17]. Twenty seven soil extracts where collected from each of the two valley bottoms.

\subsection{Measurements}

With a strong concern about data accuracy, one set of measurements was implemented in the field and a second set in the laboratory. For the field side, the $\mathrm{pH}$ and ferrous iron concentrations were measured shortly after extraction from the flooded rice soils and their introduction into anaerobic boxes. For this purpose the extracts were diluted 5 times to get the soil solutions [18]. A pH meter was then used to determine the current acidity in the samples, and a reflectometer to quantify $\mathrm{Fe}^{2+}$ concentrations $[19,20]$. For the laboratory side, grain size sorting using standardized American Society for Testing and Materials (ASTM) sieves and sedimentometry yielded the clay proportions (\%Clay) for each depth according to US Department of Agriculture (USDA) classification. In addition, the organic matter content (\%OM) was assessed by weighting and oven drying at $900^{\circ} \mathrm{C}$. Finally, the dry bulk density $(\mathrm{Db})$ at each individual depth was obtained by weighting and oven drying at $105^{\circ} \mathrm{C}$.

\subsection{Statistical Analysis}

Since one of the objectives was to compare Tiefora and Moussodougou on a sound ground, statistical hypotheses testing was required [21]. Prior to the choice and the implementation of the tests, three conditions had to be verified: 1) the equality of the number of samples, 2) the normality of samples underlying populations, and 3) the equality of variances. These checks were performed with the previous five response variables $\left(\mathrm{Fe}^{2+}, \mathrm{pH}\right.$, \%Clay, $\mathrm{Db}$ and \%OM) for both sites and at each of the depths. When the three conditions were fulfilled, a One-Way ANOVA + Fisher grouping could be applied to check if there was any significant difference at the depth under consideration for the two sites. The depth is considered as the independent variable. The null hypothesis was that the five response variables are equivalent when the two sites are compared depth per depth.

In case one of the prerequisite conditions was missing, a non-parametric hypothesis testing model was applied [22].

\subsection{Geochemistry}

A geochemical analysis endeavored to find the underlying causes of the differences revealed by the statistical hypothesis testing. This analysis considered the chemical 


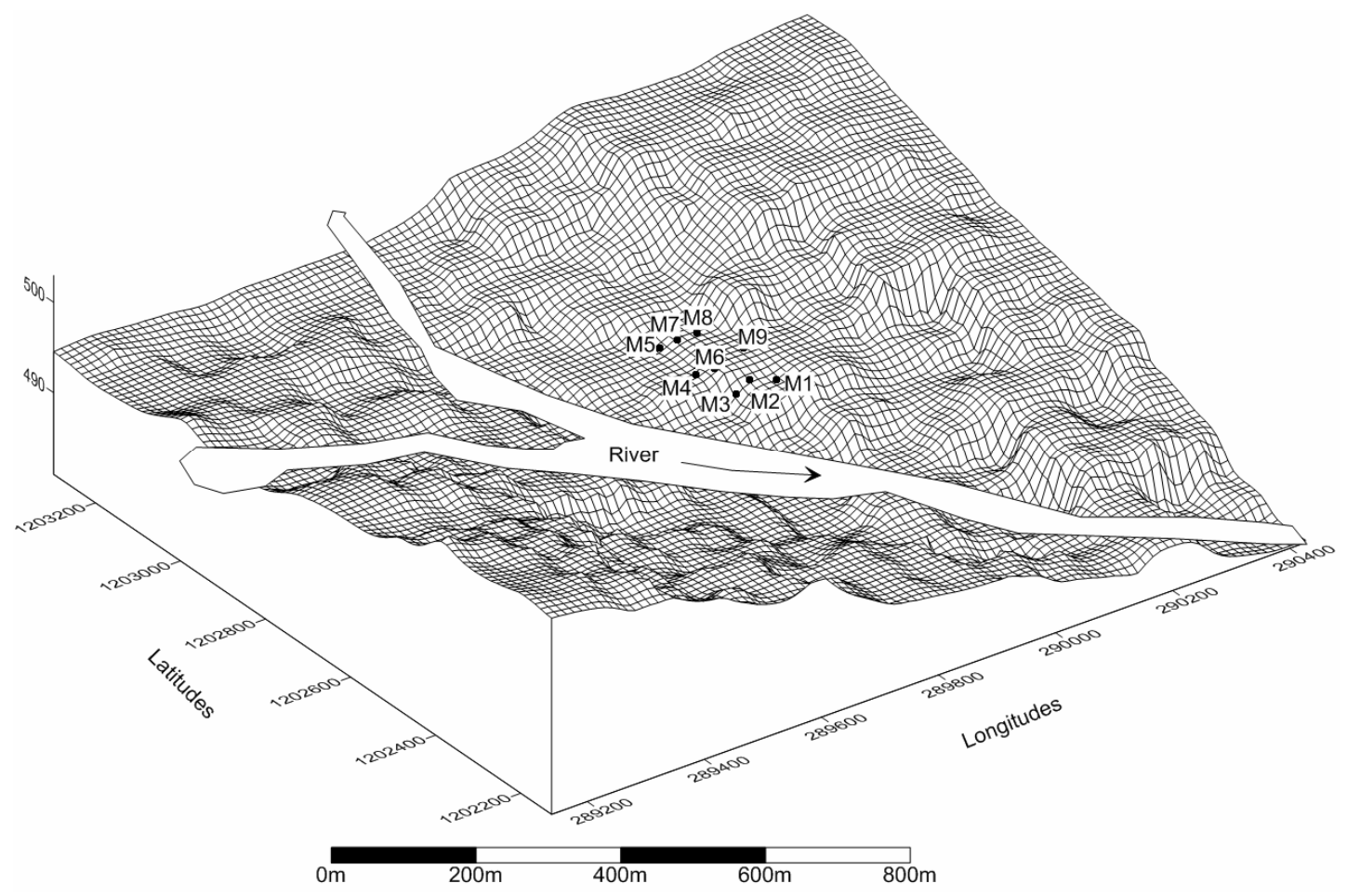

Figure 1. Moussodougou valley with the "M" soil sampling point locations. A randomized block sampling was implemented. Three soil extracts where collected from 30,50 and $100 \mathrm{~cm}$ depth in each random " $M$ " point inside a "block". The blocks represent different longitudinal and transversal sloping conditions. The corresponding area by symmetry on the right bank of the river was assumed to have similar sloping conditions.

reactions related to iron oxido-reduction as well as the bacterial involvement as catalysts [23,24]. Tropical Savannah soils are predominantly hematite $\left(\mathrm{Fe}_{2} \mathrm{O}_{3}\right)$ and precipitates of iron(III)-hydroxide $\left(\mathrm{Fe}(\mathrm{OH})_{3}\right)$. Therefore oxido-reduction processes are alternatively occurring in the wet valley bottom soils $[14,25,26]$. The key reactions, particularly in hematite dominant environment, were selected and examined in order to predict their impact on the increase and/or decrease of the two main response variables in iron toxicity, i.e. $\mathrm{Fe}^{2+}$ concentrations and the acidity indicator $\mathrm{pH}$ [27]. Consequently, a table was drawn, showing each important reaction involving hematite or iron(III)-hydroxide with its impact on the change of ferrous iron concentration and the acidity. Corresponding to the reactions in this table, crop growing season-wet or dry-in Tiefora and Moussodougou were inserted according to the assumed oxido-reduction process occurring. This analysis led to uncovering the reasons behind the differences between the two sites and to practical proposals to prevent or reduce iron toxicity and acidity.

\section{Results and Discussions}

\subsection{Conditions Check for Hypotheses Testing}

The two first conditions required for enabling the application of One-Way ANOVA-equality of sample num- bers and normality-were rather well met using Anderson-Darling normality statistic [22]. All the samples of the five response variables have eight or nine elements. If the significance level is set $\alpha=5.0 \%$, all the samples are normally distributed except at 3 depths for 2 variables. These depths are $50 \mathrm{~cm} / \mathrm{pH}$ and $100 \mathrm{~cm} / \% O M$ in Tiefora, and $100 \mathrm{~cm} / \% \mathrm{OM}$ in Moussodougou.

The related p-values of Anderson-Darling statistics are slightly smaller than 5\% (Figure 2). However, this does not constitute a real obstacle to the use of One-Way ANOVA since this test is less sensitive to departure from normality [21].

The equality of variances check constituted a greater obstacle to the application of One-Way ANOVA (Figure 3). The computations performed for the five response variables at the three depths in Tiefora and Moussodougou showed that the samples of $\mathrm{Fe}^{2+}$ and of \%Clay provided Levene p-values smaller than 5\% [16,28]. Therefore, the variances are not equal in both Tiefora and Moussodougou for these two variables at the related depths. Consequently, a hypothesis test model less sensitive to the equality of variances was applied, namely the non-parametric Welch 2-sample t-Test [29,30].

\subsection{Statistical Results}

The application of hypotheses testing for comparing the 


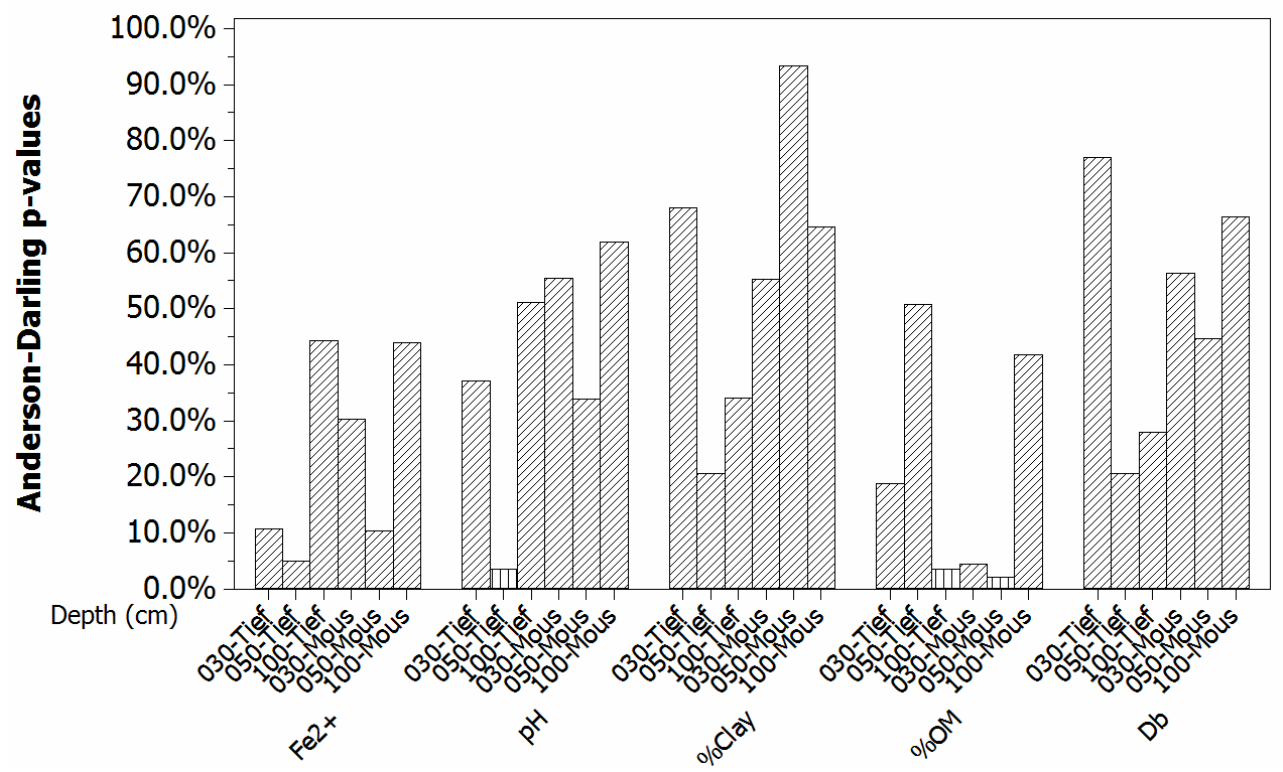

Figure 2. Normality check for the 5 response variables. The p-values of the Anderson-Darling statistics are significant at $\alpha=$ $5 \%$ except for the three depths with vertical fill pattern $(50 \mathrm{~cm} / \mathrm{pH}$ and $100 \mathrm{~cm} / \% O M$ for Tiefora; $100 \mathrm{~cm} / \% O M$ for Moussodougou). Except these three depth-variables, all the other samples had a normal distribution.

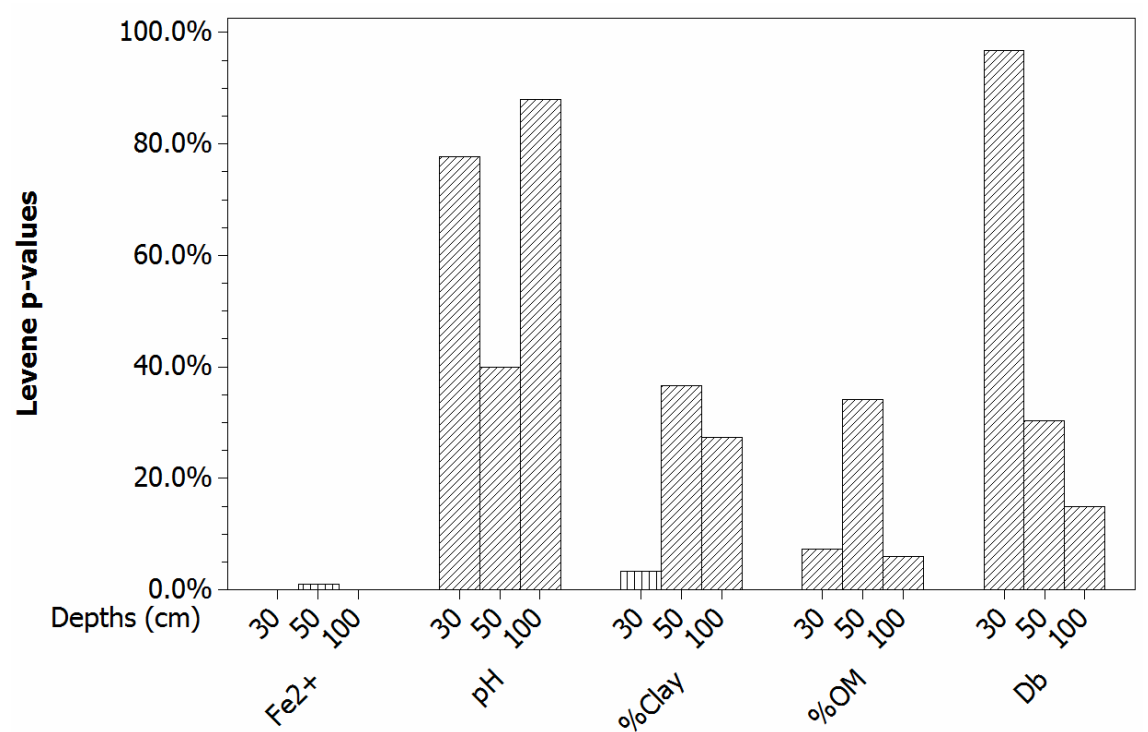

Figure 3. Equality of variances check for the five response variables. The Levene statistic p-values are greater than $5 \%$ for three response variables- $\mathrm{pH}, \% \mathrm{OM}$ and $\mathrm{Db}-$ but are smaller for $\mathrm{Fe}^{2+}$ at all depths and \%Clay at depth $30 \mathrm{~cm}$ (vertical fill pattern of the bars). For these four depths, the related variables are not equivalent in variance in the two sites of Tiefora and Moussodougou [31].

two sites-Welch 2-samples t-Test, One Way ANOVA + Fisher Grouping-do not lead to significant differences except for $\mathrm{Fe}^{2+}$ and the $\mathrm{pH}$. Both sites were similar in the corresponding depths when considering the clay content (\%Clay), the organic matter content (\%OM) and the dry bulk density (Db). For example, the organic matter content for all the three layers are equivalent in both sites, with an average varying between $6 \%$ and $8 \%$ and a p-value of $87 \%$ (Table 1 and Table 2). Similarly an average
1.3 - 1.5 dry bulk density was found equivalent for both sites, and the clay content \%Clay was found not significantly different with the averages varying from $20 \%$ - 40\%.

As regards with iron, the results show that Moussodougou is more exposed to ferrous iron intoxication than Tiefora. The application of Welch 2-samples t-Test to compare the ferrous iron $\mathrm{Fe}^{2+}$ concentrations at the three individual depths in the two sites brings about two important differences (Figure 4). 
Table 1. One-way ANOVA: OM (\%) versus Depth $(\mathrm{cm})$ in Tiefora and Moussodougou.

\begin{tabular}{cccccc}
\hline Source & $\begin{array}{c}\text { DF(degre of } \\
\text { freedom) }\end{array}$ & $\begin{array}{c}\text { SS(sum of } \\
\text { squares) }\end{array}$ & $\begin{array}{c}\text { MS(mean } \\
\text { squares) }\end{array}$ & $\begin{array}{c}\text { F of } \\
\text { Fisher }\end{array}$ & p-value \\
\hline Depth $(\mathrm{cm})$ & 5 & 19.5 & 3.9 & 0.37 & $87.0 \%{ }^{(\mathrm{a})}$ \\
Error & 48 & 506.5 & 10.6 & & \\
Total & 53 & 526.1 & & & \\
\hline
\end{tabular}

$\mathrm{S}=3.2 ; \mathrm{R}^{2}=3.70 \% ; \mathrm{R}^{2}$ adj $=0.00 \%$. ${ }^{\text {(a) }} \mathrm{p}$-value greater than $5 \%$; all the $\% \mathrm{OM}$ values are similar in Tiefora and Moussodougou.

Table 2. Grouping information using fisher method.

\begin{tabular}{cccc} 
Depth $(\mathrm{cm})$ & Number of observations & Mean(\%OM) & Grouping $^{(\mathrm{a})}$ \\
\hline 030-Tief & 9 & 8.0 & $\mathrm{~A}$ \\
030-Mous & 9 & 7.6 & $\mathrm{~A}$ \\
050-Tief & 9 & 7.4 & $\mathrm{~A}$ \\
050-Mous & 9 & 6.1 & $\mathrm{~A}$ \\
100-Tief & 9 & 7.0 & $\mathrm{~A}$ \\
100-Mous & 9 & 7.2 & $\mathrm{~A}$ \\
\hline
\end{tabular}

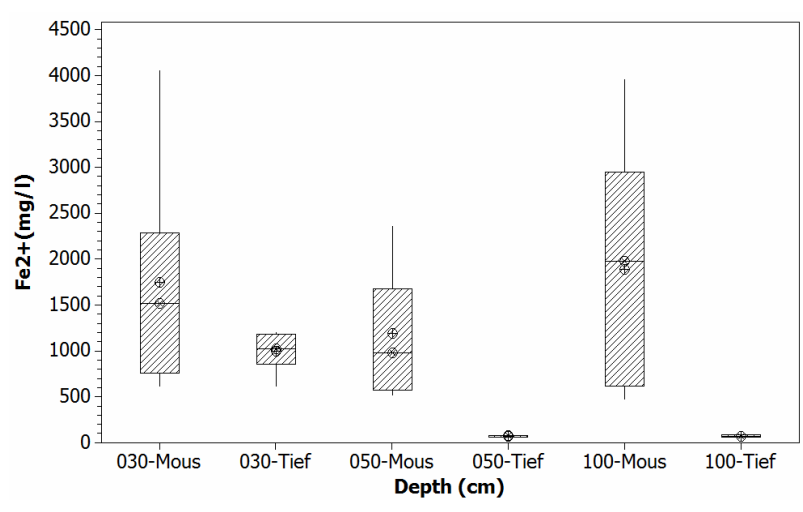

Figure 4. Comparison of ferrous iron concentrations on the sites of Tiefora and Moussodougou. While the $\mathrm{Fe}^{2+}$ concentrations were quite uniform in Moussodougou, they dropped in Tiefora below $30 \mathrm{~cm}$ depth. Only the top $30 \mathrm{~cm}$ had comparable ferrous iron content in both sites.

First, while $\mathrm{Fe}^{2+}$ concentrations were not significantly different in the $30 \mathrm{~cm}$ top soil in both sites, they were much higher in Moussodougou than in Tiefora at depths 50 and $100 \mathrm{~cm}$. The values were some $1100 \mathrm{mg} / \mathrm{l}$ higher in Moussodougou (significant at $\alpha=5 \%$ ), and even more than $1800 \mathrm{mg} / \mathrm{l}$ higher at depth $100 \mathrm{~cm}$ (Table 3). The second remarkable aspect was that while the ferrous iron gets a quite uniform concentration (no significant p-value) in the whole $100 \mathrm{~cm}$ soil profile in Moussodougou, it suddenly drops to less than $100 \mathrm{mg} / \mathrm{l}$ underneath $30 \mathrm{~cm}$ in Tiefora [17]. Such discrepancies are revelatory of different biochemical reactions that will be addressed in the geochemical analysis section below. At least the high concentrations show why the iron toxicity is a bigger issue-reaching $50 \%$ of the farm plots-in Moussodougou than in Tiefora ( $10 \%$ of the farm plots).

The second response variable that made a real differ- ence between the two sites was the acidity indicator, the $\mathrm{pH}$. As the result of the application of One-Way ANOVA + Fisher grouping, it comes again that the top $30 \mathrm{~cm}$ draws the attention: Moussodougou with its average 5.7 is significantly more acidic than Tiéfora ( $p$-value $=0.4 \%$ ). In the layers underneath till $100 \mathrm{~cm}$, it remains more acidic (Table 4 and Table 5). However, compared with for example pyrite soils ( $\mathrm{pH} 2-4$ ) exposed to oxidation, the $\mathrm{pH}$ values were rather moderately acid, although the value can decrease to almost 4 in some layers, particularly in Moussodougou (Figure 5) [32,33]. Though this is not surprising due to the hematite dominant environment, it leads in combination with a high ferrous iron concentration to a more severe iron toxicity in Moussodougou (score 7) [34].

\subsection{Geochemical Analysis}

The statistical analysis of the variables making a significant difference between Tiefora (a double-season irrigation scheme) and Moussodougou (a single-season spate irrigation scheme) brings about two important questions: 1) Why is Moussodougou more "ferrous" and more acidic (and thus more exposed to iron toxicity) than Tiefora? 2) How ferrous iron was mainly concentrated in the 30 $\mathrm{cm}$ topsoil of Tiefora? To address these questions, some biogeochemical analysis would be helpful.

Though sulfate might be present to some extent, oxido-reduction processes related to iron were the most important in hematite dominant soils, such as found in the valley bottom soils of Tropical Savannah [10,35]. Acid sulfate soils - more often found in coastal flood-plains and mangroves [32,36] —are known to be very acidic when exposed to oxidation. The $\mathrm{pH}$ can decrease to less than 3 when exposed to drainage for example. In Tropical Savannah inland valley bottoms, like Tiefora and Moussodougou, the main reactions involve the oxidation and the reduction of hematite $\left(\mathrm{Fe}_{2} \mathrm{O}_{3}\right)$ and the precipitation of Iron (III) hydroxide $\mathrm{Fe}(\mathrm{OH})_{3}$. These reactions may be catalyzed (up to million times) by iron reducing or oxidizing bacteria. The predominance of various iron (III) species may also be pH dependent $[24,37,38]$. The principal reactions involved valleys oxido-reduction are:

Oxidation of pyrite: Simultaneous increase of $\mathrm{Fe}^{2+}$ and acidity [39]:

$$
\mathrm{FeS}_{2}+14 \mathrm{Fe}^{3+}+8 \mathrm{H}_{2} \mathrm{O} \rightarrow 15 \mathrm{Fe}^{2+}+2 \mathrm{SO}_{4}^{2-}+16 \mathrm{H}^{+}
$$

Precipitation of Fe(III) hydroxide: Simultaneous decrease of $\mathrm{Fe}^{2+}$ acidity [40]:

$$
15 \mathrm{Fe}^{2+}+\mathrm{O}_{2}+\mathrm{H}^{+} \rightarrow \mathrm{Fe}(\mathrm{OH})_{3}+3 \mathrm{Fe}^{3+}
$$

Formation of hematite (oxidation): Decrease of $\mathrm{Fe}^{2+}$ and increase of acidity [41,42]: 
Table 3. Tiefora versus. Moussodougou-Welch 2-samples t-Test for $\mathrm{Fe}^{2+}$ at three depths.

\begin{tabular}{ccccccc}
\hline Depths & $\mu_{\text {Mousso- } \mu_{\text {Tiefo }}(\mathrm{mg} / \mathrm{l})}$ & 95\% Confidence interval & t-Test of diffrce & Deg. of freedom & p-Value & Iron stratum $^{(\mathrm{b})}$ \\
\hline $30 \mathrm{~cm}$ & 750 & {$[-100 ; 1600]$} & 2.0 & 8 & $7.7 \%$ & $\mathrm{~A}-\mathrm{A}$ \\
$50 \mathrm{~cm}$ & 1110 & {$[601 ; 1625]$} & 5.0 & 7 & $0.1 \%^{(\mathrm{a})}$ & B-A \\
$100 \mathrm{~cm}$ & 1820 & {$[855 ; 2780]$} & 4.3 & 8 & $0.2 \%^{(\mathrm{a})}$ & C-A \\
\hline
\end{tabular}

${ }^{(a)}$ Significant at $\alpha=5.0 \%$. The corresponding $\mathrm{Fe}^{2+}$ values are significantly different in Tiefora compared to Moussodougou. ${ }^{(\mathrm{b})}$ The first letter stands for Tiefora and the letter for Moussodougou. $\mathrm{Fe}^{2+}$ concentrations are comparables at $30 \mathrm{~cm}$ on both sites. But at $50 \mathrm{~cm}$ and $100 \mathrm{~cm}, \mathrm{Fe}^{2+}$ concentrations are much higher in Moussodougou than Tiefora.

Table 4. One-way ANOVA: pH versus depth level (cm).

\begin{tabular}{cccccc}
\hline Source: & DF (degre of freedom) & SS (sum of squares) & MS (mean squares) & F of Fisher & P-value \\
\hline Depth $(\mathrm{cm})$ & 5 & 7.79 & 1.557 & 4.08 & $0.4 \%{ }^{(\mathrm{a})}$ \\
Error & 48 & 18.3 & 0.381 & & \\
Total & 53 & 26.1 & & & \\
\hline
\end{tabular}

$\mathrm{S}=0.617 ; \mathrm{R}^{2}=29.90 \% ; \mathrm{R}^{2}$ adj $=22.50 \% ;{ }^{(\mathrm{a})}$ Significant at $\alpha=0.05$.

Table 5. Fisher grouping applied to $\mathrm{pH}$ in the two sites of Tiefora and Moussodougou.

\begin{tabular}{cccc}
\hline Depth (cm) & Number of observations. & Mean & Grouping $^{(\mathrm{a})}$ \\
\hline 030-Tief & 9 & 6.4 & $\mathrm{~A}$ \\
030-Mous & 9 & 5.7 & $\mathrm{C}$ \\
050-Tief & 9 & 6.3 & $\mathrm{AB}$ \\
050-Mous & 9 & 5.7 & $\mathrm{C}$ \\
100-Tief & 9 & 6.6 & $\mathrm{~A}$ \\
100-Mous & 9 & 5.8 & $\mathrm{BC}$ \\
\hline
\end{tabular}

${ }^{\text {(a) }}$ Means that do not share a letter are significantly different.

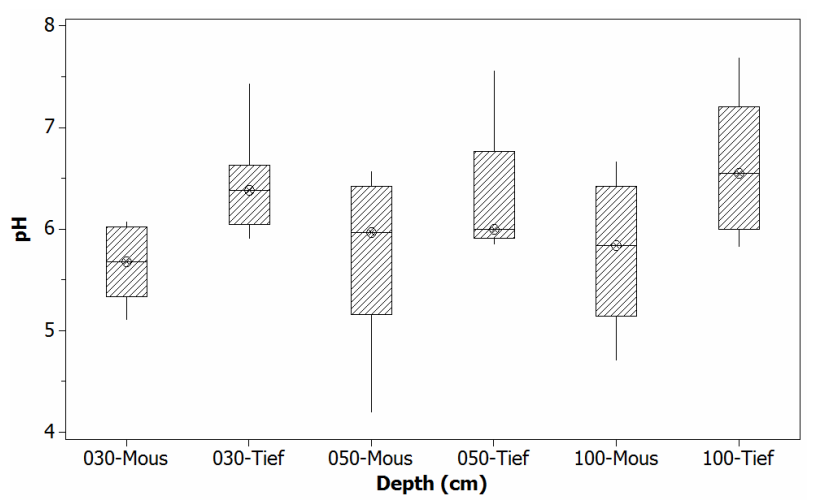

Figure 5. Comparison of $\mathrm{pH}$ on the sites of Tiefora and Moussodougou.

$$
4 \mathrm{Fe}^{2+}+\mathrm{O}_{2}+4 \mathrm{H}_{2} \mathrm{O} \rightarrow 2 \mathrm{Fe}_{2} \mathrm{O}_{3}+3 \mathrm{H}^{+}
$$

Reduction of Hematite: Increase of $\mathrm{Fe}^{2+}$ and decrease of acidity [43]:

$$
2 \mathrm{Fe}_{2} \mathrm{O}_{3}+\mathrm{CH}_{2} \mathrm{O}+8 \mathrm{H}^{+} \rightarrow 4 \mathrm{Fe}^{2+}+\mathrm{CO}_{2}+5 \mathrm{H}_{2} \mathrm{O}
$$

The impacts of the processes-reported in Equations (1) to (4) - on the changes in ferrous iron concentrations and the acidity measured by the $\mathrm{pH}$ are of special interest. It is noteworthy that the velocity of these changes can be boosted million times by iron oxidizing (IOB) and iron reducing bacteria (IRB) [23,24]. The oxidation of pyrite (Equation (1)) when exposed to air or leaching leads to a strong simultaneous increase of both $\mathrm{Fe}^{2+}$ and acidity. Pyrite is mainly formed in marshy tidal mangroves and coastal floodplains with very low $\mathrm{pH}$ [26,39]. In fact, a $\mathrm{pH}$ below 3.5 suffices to attest the presence of sulfuric acid resulting from pyrite oxidation [32]. For this reason, it seems reasonable to admit that pyrite is not much in the soils of Tiefora and Moussodougou having a moderate acid $\mathrm{pH}$ when exposed to air and which soils were weathered from hematite (Table 6). The precipitation of iron III hydroxide (Equation (2)) leads to the simultaneous decrease of acidity and ferrous iron. This phenomenon was observed particularly in Moussodougou [40]. It is essentially observable during spate irrigation in Moussodougou, but also during the two-season irrigation periods in Tiefora (Table 6).

From Equations (3) and (4), it can be drawn how the redox processes result in a higher ferrous iron concentration and a more acidic environment in Moussodougou than in Tiefora. The oxidation of hematite will particularly occur in the soil of Moussodougou during the dry season (height months). During that period, ferrous iron concentration decreases, but the acidity increases (Equation (3) and Table 6). This observation is confirmed by oxidizing subsurface drainage experiments on rice growing microplots with hematite soils [44]. However, during the wet season with spate irrigation the reduction processes in Moussodougou resume on the hematite (Equation (4)), leading to an increase of the ferrous iron concentration. The degree reached by this increase suggests an important activity iron reducing bacteria (IRB) [38]. This high level of bacterial activity may be linked to river use as water resource for irrigation. The increase of $\mathrm{Fe}^{2+}$ concentration in a medium already more acidic due the previous dry season makes the soluble ferrous iron more dominant in the soil of Moussodougou compared 
Table 1. Dominant iron redox reactions in valley bottoms.

\begin{tabular}{|c|c|c|c|c|}
\hline Reference & Reactions & {$\left[\mathrm{Fe}^{2+}\right]$} & Acidity & Site \\
\hline 1 & Oxidation Pyrite + IRB & ススス & ススス & \\
\hline 2 & Precipitation of Fe(III) hydroxide + IOB & ע & ע & $\begin{array}{l}\text { Mousso wet } \\
\text { Tiefo wet season }\end{array}$ \\
\hline 3 & Oxidation of Hematite + IOB ${ }^{(\mathrm{b})}$ & ע & $\pi$ & Mousso dry season \\
\hline 4 & Reduction of Hematite + IRB ${ }^{\text {(a) }}$ & $\pi$ & ע & $\begin{array}{l}\text { Mousso wet season } \\
\text { Tiefo wet season }\end{array}$ \\
\hline
\end{tabular}

(a) IRB = Iron reducing bacteria; ${ }^{(b)}$ IOB = Iron oxidizing bacteria; $\boldsymbol{\nearrow}$ = increase; $\boldsymbol{\searrow}$ = decrease.

with Tiefora. Finally, we suggest that the high $\mathrm{Fe}^{2+}$ concentration in the $30 \mathrm{~cm}$ top soil of Tiefora (the only one similar to Moussodougou) is due to a higher IRB activity in this layer.

Water management aiming to alleviate iron toxicity in Tropical savannah valley bottoms will have to deal with these three processes: 1) precipitation of $\left.\mathrm{Fe}(\mathrm{OH})_{3}, 2\right)$ oxidation hematite and iii) reduction of hematite. Fortunately, the precipitation of $\mathrm{Fe}(\mathrm{OH})_{3}$, which is one of the most spectacular effects observable at the resurging points in the valley, is actually an ally in this fight. It is the only one simultaneously decreasing both $\mathrm{Fe}^{2+}$ and the acidity. It is often observable in open drains in the valleys. Therefore, open channel subsurface drainage will contribute to improve the fertility of the soils. In the same line, oxidation of hematite by bringing oxygenated water in the rice rootzone will decrease ferrous iron concentration, unfortunately along with an increase of acidity in short run. An incorporation of limestone $\left(\mathrm{CaCO}_{3}\right)$ will certainly reduce acidity in short run.

In very severe cases of iron toxicity, biotechnology resources can be investigated. A few studies have already been executed to identify the type of iron or sulfate reducing bacteria in Tropical Savannah valley bottom irrigated rice fields $[10,12,45]$. There is a need for more investigations in this climatic zone about the positive impact of iron oxidizing bacteria (Thiobacillus ferrooxidans, Ferrobacillus ferrooxidans ...) in terms of reinstatement of ferric iron $\mathrm{Fe}^{3+}$ and the reduction of acidity.

Finally, it appears that practicing two-season rice growing presents less risk to develop iron toxicity in the valley bottoms. Therefore, the numerous traditional valley where farmers are practicing a single-season spate irrigation would have to be developed into at least a double-season modernized rice irrigation scheme.

\section{Conclusion}

There exists more risk to develop iron toxicity in a single-season compared with a double-season valley bottom irrigated rice in Tropical Savannah hematite rich soils. On the contrary of pyrite oxidation that leads to a simultaneous increase in $\mathrm{Fe}^{2+}$ concentration and acidity in costal floodplains and mangroves, the oxidation of hematite decreases $\mathrm{Fe}^{2+}$ but moderately increases soil acidity in Tropical Savannah. However, very high ferrous iron concentration may also occur (more than $3000 \mathrm{mg} / \mathrm{l}$ ). We found a ferrous iron concentration 750 - $1800 \mathrm{mg} / \mathrm{l}$ higher in the single-season valley bottom in the $100 \mathrm{~cm}$ top soil profile. The $\mathrm{pH}$, with an average of 5.7, was also significantly more acidic in the single season valley bottom, making ferrous iron more available in solution. During the dry season in which no crop was grown and the soil dried, acidity increased in the hematite. Therefore, our results show that there is a well founded interest to modernize traditional single-season spate irrigated rice into modern double-season schemes, equipped with an efficient open/pipe subsurface drainage system.

\section{Acknowledgements}

We are indebted to several institutions for the support provided to this research project. In this regard, we express our sincere gratitude to the Economic and Monetary Union of West Africa (UEMOA), The Netherlands Organization of International Cooperation in Higher Education (NUFFIC), French Development Agency (AFD), and the International Foundation for Science, Sweden (IFS).

\section{REFERENCES}

[1] N. V. Nguyen and A. Ferrero, "Meeting the Challenges of Global Rice Production,” Spinger-Verlag, Vol. 4, 2006, pp. 1-9.

[2] E. J. Wailes, "Rice: Global Trade, Protectionist Policies, and the Impact of Trade Liberalization,” In: M. Ataman and J. C. Beghin, Eds., Global Agriculural Trade and Developing Countries, The Wolrd Bank, Washington DC, 2005, p. 327.

[3] FAO, "Trends on Yield and Productivity of Modern Rice in Irrigated Rice Systems in Asia,” The FAO Expert Consultation on Technological Evolution and Impact for Sustainable Rice Production in Asia and the Pacific, Thailand, 1996.

[4] B. Schultz, H. Tardieu and A. Vidal, "Role of Water Management for Global Food Production and Poverty Alleviation,” Irrigation and Drainage, Vol. 58, No. S1, 2009, 
pp. S3-S21.

[5] M. C. Masiyandima, N. van de Giesen, S. Diatta, P. N. Windmeijer, et al., "The Hydrology of Inland Valleys in the Sub-Humid Zone of West Africa: Rainfall-Runoff Processes in the M'be Experimental Watershed," Hydrological Processes, Vol. 17, No. 6, 2003, pp. 1213-1225.

[6] F. Lançon and H. D. Benz, "Rice Imports in West Africa: Trade Regimes and Food Policy Formulation,” Pro-Poor Development in Low Income Countries, 2007.

[7] Institut National de la Statistique et de la Démographie [INSD-BF], "Indices du commerce extérieur du Burkina Faso [Indices of External Trade of Burkina Faso], Ouagadougou (Burkina Faso),” 2011.

[8] Y. Dembele, H. Yacouba, A. Keïta and H. Sally, “Assessment of Irrigation System Performance in South-Western Burkina Faso," Irrigation and Drainage, Vol. 61, No. 3, 2012, pp. 3006-3015.

[9] WARDA, "Iron Toxicity in Rice-based Systems in West Africa, Cotonou (Benin),” 2006.

[10] B. S. Ouattara, “Contribution à L'étude des Bactéries Réductrice du fer et du Sulfate dans les sols de Rizière de la Vallée du Kou (Burkina Faso) [Contribution to the Study of Iron and Sulfate Reducing Bacteria in the Vallee du Kou Valley Bottom Rice Field],” Microbiologie, Celular Biology, Université de Provence Aix-Marseille I, AixMarseille, 1992.

[11] E. A. Somado, R. G. Guei and S. O. Keya, "NERICA: The New Rice for Africa-A Compendium,” Africa Rice Center, Benin, 2008, 210 p.

[12] D. Dianou, "Etude des Bactéries Sulfato-Réductrices, Méthanotrophes et des Archaeobacteries Méthanogènes dans les sols de Rizière: Influences des Interactions sur la Production du riz et sur L'émission de Méthane Dans L'Atmosphère [Study of the Sulfate Reducing Bacteria, the Methanotroph and the Methanogenic Archaeobacteria in Rice Growing Soils: Influence of the Interactions on Rice Production and the Methane Emission in the Atmosphere]," Applied Biological Sciences, University of Ouagadougou, Ouagadougou, 2005.

[13] M. C. Peel, B. L. Finlayson and T. A. McMahon, "Updated World Map of the Koppen-Geiger Climate Classification," Hydrology and Earth System Sciences, Vol. 11, 2007, pp. 1633-1644.

[14] O. C. Spaargaren and J. A. Deckers, “Climate,” In: D. Hillel, C. Rosenzweig, D. Powlson et al., Eds., Encyclopedia of Soils in the Environment, Academic Press, New York, 2004, pp. 512-519. http://dx.doi.org/10.1016/B0-12-348530-4/00012-6

[15] R. L. Mason, R. F. Gunst and J. L. Hess, "Statistical Design and Analysis of Experiements with Appliations to Engineering and Science,” 2nd Edition, Willey-Interscience, 2003.

[16] D. Rumsey, “Statistics II for Dummies,” Wiley Pusblishing Inc., 2009.

[17] A. Keïta, B. Schultz, H. Yacouba and L. G. Hayde, “Clay and Ferrous Iron Stratifications in a Tropical Savannah Valley Bottom Soil under Irrigated Rice," Academia Journal of Agricultural Research, Vol. 1, No. 11, 2013, pp. 204-210.

[18] M. B. Murray, "Environmental Chemistry of Soils," Oxford University Press, Oxford, 1994.

[19] K. B. Persson, "Soil Phosphate Analysis: A New Technique for Measurement in the Field Using a Test Strip," Archaeometry, Vol. 39, No. 2, 1997, pp. 441-443. http://dx.doi.org/10.1111/j.1475-4754.1997.tb00819.x

[20] A. Keïta, “Guide D’utilisation du Réflectomètre RQFlex Plus 10 [The Reflectometer User Guide],” 2013. http://www.youtube.com/watch?v=xH8IISJ6CZU

[21] D. C. Montgomery and G. C. Runger, "Applied Statistics and Probability for Engineers," Wiley and Sons Inc., 2011.

[22] S. Boslaugh and P. A. Watters, "Statistics in a Nutshell," OReilly, 2008.

[23] J. K. Fredrickson and Y. A. Gorby, "Environmental Processes Mediated by Iron-Reducing Bacteria," Current Opinion in Biotechnology, Vol. 7, 1996, pp. 287-294. http://dx.doi.org/10.1016/S0958-1669(96)80032-2

[24] D. Emerson, J. V. Weiss and J. P. Megonigal, "Iron-Oxidizing Bacteria Are Associated with Ferric Hydroxide Precipitates (Fe-Plaque) on the Roots of Wetland Plants," Applied and Environmental Microbiology, Vol. 65, No. 6, 1999, pp. 2758-2761.

[25] W. R. Fisher and U. Schwertmann, "The Formation of Hematite from Amourphous Iron(III) Hydroxide," Clays and Clay Minerals, Vol. 23, 1974, pp. 33-37.

[26] F. R. Moormann and N. V. Breemen, "Rice: Soil, Water, Land, Los Banos Laguna (Philippines),” International Rice Research Institute (IRRI), 1978.

[27] A. R. Conklin Jr., "Introduction to Soil Chemistry Analysis and Instrumentation,” Wiley and Sons Inc., 2005. http://dx.doi.org/10.1002/0471728225

[28] J. L. Gastwirth, Y. R. Gel and W. Miao, “The Impact of Levene's Test of Equality of Variances on Statistical Theory and Practice,” Statistical Science, Vol. 24, No. 3, 2009, pp. 343-360. http://dx.doi.org/10.1214/09-STS301

[29] B. L. Welch, “The Generalization of Student's Problem When Several Different Population Variances Are Involved,” Biometrika, Vol. 34, No. 1-2, 1947, pp. 28-35. http://dx.doi.org/10.1093/biomet/34.1-2.28

[30] C. H. Brase and C. P. Brase, "Understanding Basic Statistics,” Houghton Mifflin Company, 2007.

[31] H. Levene, "Robust Testes for Equality of Variances,” In: I. Olkin, Ed., Contributions to Probability and Statistics, Stangord University Press, 1960, pp. 278-292.

[32] T. Attanandana and S. Vacharotayan, “Acid Sufate Soils: Their Characteristics, Genesis, Amelioration and Utilization,” Southeast Asian Studies, Vol. 24, No. 2, 1986, pp. 154-180.

[33] V. A. Jacq and J. C. G. Ottow, "Iron Sulphide Accumulation in the Rhizosphere of Wetland Rice (Oryza sativa L.) as Result of Microbial Activities,” In: J. Berthelin, Ed., Diversity of Environmental Biogeochemistry, La Haye. Elsevier, 1991, pp. 453-468.

[34] IRRI, “Standard Evaluation Systems for Rice,” International Rice Research Institute, Philippines, 2002. 
[35] H. Bouwer and R. D. Jackson, "Determining Soil Properties,” In: J. Shilfgarde van, Ed., Drainage for Agriculture, Agronomy, 1974, pp. 611-672.

[36] L. J. Pons, N. V. Breemen and P. M. Driessen, "Pysiography of Coastal Sediments and Development of Potential Soil Acidity,” In: J. A. Kittrick, D. S. Fanning and L. R. Hossner, Eds., Acid Sulfate Weathering, Soil Science Society of America, 1982, pp. 1-18.

[37] F. N. Ponnamperuma, "The Chemistry of Submerged Soils," Advances in Agronomy, Vol. 24, 1972, pp. 29-96.

[38] L. Wenjing, W. Hongtao, H. Changyong and W. Reichardt, "Aromatic Compound Degradation by Iron Reducing Bateria Isolated from Irrigated Tropical Paddy Soils,” Journal of Environmental Sciences, Vol. 20, No. 12, 2008, pp. 1487-1493.

[39] F. X. Suryadi, "Soil and Water Management Strategies for Tidal Lowlands in Indonesia," Delft University of Technology, Deft, 1996.

[40] D. Rickard and G. W. Luther, "Chemistry of Iron Sulfides,” Chemistry Revisions, Vol. 107, 2007, pp. 514-562.

[41] Y. Kato, K. Suzuki, K. Nakamura, A. H. Hickman, et al., "Hematite Formation by Oxigenated Groundwater More than 2.76 Billion Years Ago,” Earth and Planetary Science Letters, Vol. 278, No. 1-2, 2008, pp. 40-49.

[42] U. Schwertmann and E. Murad, "Effects of $\mathrm{pH}$ on the Formation of Goethite and Hematite from Ferryhidrite," Clays and Clay Minerals, Vol. 31, No. 4, 1983, pp. $277-$ 284. http://dx.doi.org/10.1346/CCMN.1983.0310405

[43] N. V. Breemen, "Environmental Aspects of Acid Sulphate Soils," International Symposium on Acid Sulphate Soils, Ho Chi Minh City, 1992.

[44] H. Otoidobiga, “Etude de L’Impact du Développement et des Activités des Bactéries Sulfato-Réductrices et des Bactéries Réductrices de Fer sur le Développement Végétatif et les Rendements de riz de Submersion sous Drainage de Sub-Surface [Sudy of the Impact of Sulphate and Iron Reducing Bacteria on the Vegetative Development and the Yields of Flooded Rice under Subsurface Drainage],” Unité de Formation et de Recherche Sciences de la Vie et de la Terre, University of Ouagadougou, Burkina Faso, 2012.

[45] K. R. Butlin, M. E. Adams and M. Thomas, "The Isolation and Cultivation of Sulphate-Reducing Bacteria,” Microbiology, Vol. 3, No. 1, 1949, pp. 46-59. 